\title{
DEVELOPMENT OF A FIRE DANGER INDEX FOR EUCALYPT PLANTATIONS IN THE NORTHERN COAST OF BAHIA, BRAZIL
}

\author{
Benjamin Leonardo Alves White ${ }^{1}$, Larissa Alves Secundo White ${ }^{2}$, Genésio Tâmara Ribeiro ${ }^{3}$, \\ Paulo Alexandre Martins Fernandes ${ }^{4}$ \\ ${ }^{1}$ Biologist, M.Sc., Laboratório de Geoecologia e Planejamento Territorial, UFS, Sergipe - benjmk@ hotmail.com \\ ${ }^{2}$ Forest Engineer, M.Sc., UFS, Sergipe - larissawhite@ hotmail.com \\ ${ }^{3}$ Forest Engineer, Dr., Laboratório de Entomologia, UFS, Sergipe - genesiotr@ hotmail.com \\ ${ }^{4}$ Forest Engineer, Dr., Universidade de Trás-os-Montes e Alto Douro, Departamento de Ciências Florestais e Arquitetura Paisagista \\ e Centro de Investigação e de Tecnologias Agro-Ambientais e Biológicas - pfern@utad.pt \\ Recebido para publicação: 27/02/2012 - Aceito para publicação: 03/10/2013
}

\begin{abstract}
Economic losses caused by fires in commercial plantations of eucalypt forest has led to the development of new fire-fighting systems and methodologies. This study aimed to develop a fire danger index for eucalypt plantations in the Copener Forestal Ltda. areas located in the north coast of Bahia, Brazil, in order to improve fire control efforts. For this purpose, eight years of meteorological data were collected and correlated to forest fire occurrence through multivariate logistic regression. The proposed model (White Model) presented a better statistical performance than other models generally used in Brazil, recommended for operational use in focused area.

Keywords: Fire danger rating; fire prevention; fire suppression; fire safety.
\end{abstract}

\section{Resumo}

Desenvolvimento de um índice de perigo de ocorrência de incêndios florestais para plantações de eucalipto no litoral norte da Bahia, Brasil. Em função das perdas econômicas causadas pelo fogo em plantações comerciais de eucalipto, novas metodologias e sistemas de prevenção e combate ao fogo têm sido criados. Este estudo buscou desenvolver um índice de perigo de ocorrência de incêndio florestal em plantações de eucalipto da empresa Copener Florestal Ltda., localizada no litoral norte da Bahia, Brasil, a fim de aprimorar os sistemas de prevenção e combate ao fogo. Para tal, oito anos de dados meteorológicos foram coletados e correlacionados com a ocorrência de incêndios florestais através da regressão logística multivariada. O modelo proposto neste trabalho (Modelo White) obteve um melhor desempenho estatístico que outros modelos comumente utilizados no Brasil e, portanto, é recomendado para utilização operacional na área de estudo.

Palavras-chave: Índice de perigo; prevenção e combate ao fogo; segurança florestal.

\section{INTRODUCTION}

Fire is the main cause of damage to both native and plantation forests and is an important factor in $\mathrm{CO}_{2}$ emissions and global climate change. For this reason, the causes and effects of forest fires and methods to prevent and control them have been actively studied and developed in the last decades. The adoption of forest protection policies adequate to the characteristics of each region is required to protect and preserve forests and the environment from the harmful effects of fires.

Annual economic losses caused by fires in eucalypt plantations for pulp production are quite high in Brazil. According to Santos et al. (2006), 5832 fires were recorded in Eucalyptus spp. vegetation between 1998 and 2002, representing 30\% of all fires in any other type of vegetation in Brazil, and accounting for a burned area of 13562 hectares (16\% of the total burned area during the same period).

The occurrence and spread of forest fires are closely linked to weather conditions. Hence, knowing the relationship between meteorological variables and fire activity is very important in understanding and preventing fires. According to Soares and Batista (2007) it is possible to identify the days and times of increased probability of fire occurrence by analyzing fire weather data, and then rating fire danger, enabling adequate preparedness and pre-suppression planning to decrease potential fire damage. 
Forest fire danger rating is fundamentally important in fire management since it allows estimating, in advance, the likelihood of fire occurrence and how easily it will spread under local or regional weather conditions. Fire danger rating indexes are used in many countries and several studies have proved their accuracy. These indexes are based on easily obtained meteorological parameters, which facilitate operational usage, and require only a weather station and a trained professional.

The principal forest fire danger indexes currently in use and/or more cited in the literature are: the Angstrom Index, developed in Sweden; the Nesterov Index, developed in the former USSR and Poland; the Telicyn Logarithmic Index, developed in the former USSR; the Rodrigues and Moretti Index, developed in Argentina; the Monte Alegre formula and its subsequent modification, developed in Brazil; the National Fire Danger Rating System, developed in the U.S.; and the Canadian Forest Fire Weather System, the most widely used and adopted in different regions of the world (SOARES; BATISTA, 2007, WHITE, 2010, MELO et al., 2011).

Although it is possible to reduce expenses and time in research and development by using a previously existent model, the cost of applying an inappropriate model can be much higher since the fire fighting and fire prevention systems are based on fire danger rating (FOGARTY et al., 1998). The development, adaptation or calibration of pre-existing mathematical models to estimate the local or regional fire probability has then been carried out by several authors in recent years (eg. CASTRO et al., 2003; FERNANDES, 2005, GOULD et al., 2007; NIAZI et al., 2010; NARCISO et al., 2011; SILVA; PONTES JR., 2011).

The Monte Alegre formula, developed using data from the central region of the state of Paraná (SOARES, 1972), is the fire danger index most currently used in Brazil by forestry pulp-producing companies (including the Copener Florestal Ltda. where this research was developed) and environment protection agencies. However, according to the literature, this index is not the most appropriate to assess the likelihood of forest fire occurrence throughout Brazil, namely in the midwest (NARCISO et al., 2011), northeastern (WHITE, 2010; WHITE et al., 2011), north (SILVA; PONTES JR., 2011) and even in the southeast (MAFALDA et al., 2009) regions of the country.

A mathematical model to predict fire occurrence in eucalypt plantations on the north coast of Bahia, based on easily obtained weather parameters, was developed in this study. It was assumed that the existing fire danger index models are not as good as an index based on local data. The need to improve the effectiveness of fire management activities and the excessive fire-caused damage to eucalypt plantations in the study area justifies this work.

\section{METHODOLOGY}

\section{Characterization of the focused area}

The focused area is located in the north coast of Bahia, between latitudes $11^{\circ} 15^{\prime} \mathrm{S}-12^{\circ} 30^{\prime} \mathrm{S}$ and longitudes $37^{\circ} 30^{\prime} \mathrm{W}-38^{\circ} 45^{\prime} \mathrm{W}$, with elevations from 0 to $300 \mathrm{~m}$. It is part of the Copener Florestal Ltda. facilities which have 100,000 ha planted with hybrids eucalypt resulting, most of, by the crossing between Eucalyptus grandis (Hill ex. Maiden) x Eucalyptus urophylla (S. T. Blake) (COPENER, 2010) (Figure 1).

Inhambupe, town where the research station of the company is located, has a semi-arid climate, with mean annual temperature of $24^{\circ} \mathrm{C}$, annual rainfall of $917 \mathrm{~mm}$ and the rainy season from April to July (VIEIRA et al., 2005). The Atlantic Forest and Caatinga biomes are present in the region (INSTITUTO BRASILEIRO DE GEOGRAFIA E ESTATÍSTICA (IBGE), 2010).

\section{Data processing}

This research was developed based on data from the "Salgado" weather station located in Inhambupe at an altitude of $233 \mathrm{~m}$, latitude $11^{\circ} 50^{\prime} 42^{\prime \prime} \mathrm{S}$ and longitude $38^{\circ} 22^{\prime} 02^{\prime \prime} \mathrm{W}$. The relation between weather parameters and forest fire occurrence was analyzed using daily meteorological data from January 2002 to December 2009, comprising a total of 2922 days (8 years). Variables included air temperature at 9:00 am, air temperature at 1:00 pm, maximum daily air temperature, minimum daily air temperature, relative humidity at 9:00 am, relative humidity at 1:00 pm, daily average wind speed, daily rainfall and the number of consecutive days with rainfall greater or equal than $2 \mathrm{~mm}$. 


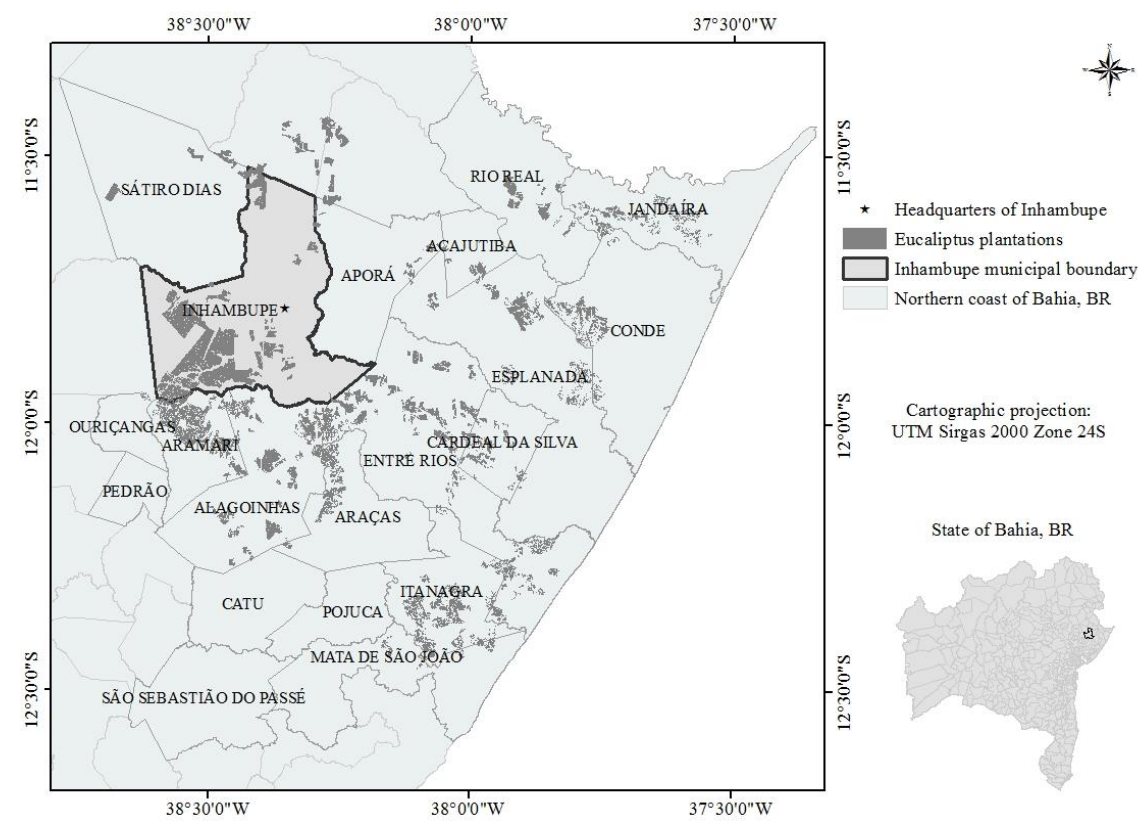

Fonte: WHITE, 2013.

Figure 1. Focused area including the eucalypt plantations of the Copener Florestal Ltda. Company.

Figura 1. Área de estudo, mostrando a localização das plantações de eucalipto da empresa Copener Florestal Ltda.

\section{Modelling the likelihood of daily fire occurrence}

Modelling of binary data is adequately handled by logistic regression, which allows predicting the values taken by a binomial categorical variable from a number of explanatory variables (AGRESTI, 1996). Fire danger rating studies are often based on logistic regression, which conveniently approaches the likelihood of fire occurrence from a probabilistc point of view (ANDREWS et al., 2003). Fire-day probabilites produced by the model can then be interpreted in terms of the associated uncertainty (POLLACK, 2003).

Logistic regression was used to build a model for the daily probability of fire occurrence. Fire occurrence data were categorized in binary form, where the value " 1 " represents days with fire, and " 0 " represents days without fire. The nominal dependent variable (occurrence of fire) was modeled using the forward stepwise procedure to select which of the independent variables better explain its variation. The statistical analysis was carried out with the software JMP version 7.0. The statistical significance level was set at $\alpha=0.05 \%$.

\section{Delineation of fire danger classes}

Based on the assumption that the number of days in each class has an inverse correlation with the danger category (the greater the danger, the lower the number of days; and the lower the danger, the greater the number of days), and that the number of fire days has a direct relationship with the danger class (the higher the danger class, the higher the number of fire days) (NUNES et al., 2007; NUNES et al., 2010), several tests were carried out to define the values for each danger class, so that the assumptions of Nunes would be met.

\section{Model performance}

The efficiency of the developed model to predict fire occurrence was compared to several other indexes commonly cited in the literature and used in Brazil (Angstrom Index, Telicyn Logarithmic Index, Rodríguez and Moretti Index, Monte Alegre Formula, Modified Monte Alegre Formula and Canadian Fire Weather Index) (SOARES; BATISTA, 2007; NUNES et al., 2007; WHITE, 2010). This comparison made possible the determination of which models best suit to the focused area. 
Statistical performance was evaluated using the coefficient of determination $\left(\mathrm{R}^{2}\right)$ and the area under the ROC curve (AUC) analysis, which is independent of arbitrary decision criteria and hence is adequate to compare alternative models. As a cutoff to declare the event (i.e. day with fire) the probability of 0.50 was assumed. The Skill Score analysis was also used. It is based on a contingency table containing the observed values and the predicted values for an event in the population (SAMPAIO, 1999).

To apply the Skill Score analysis, the indexes were classified in two categories, respectively associated with probable fire and with the absence of fire. To standardize this procedure, fire-event days were considered for the danger classes "Medium" or "Moderate" and for those more extreme, whereas nofire days corresponded to classses "Null", "Small", "Low", "Very Low" and "Light". Such standardization has been adopted based on the works of Sampaio (1999), Palheiro et al. (2006), Nunes et al. (2007), Mafalda et al. (2009), White (2010) and White et al. (2011).

\section{RESULTS AND DISCUSSION}

\section{Modeling the daily probability of fire occurrence}

Of eight years of analyzed data, only in 221 days were fire occurrences $(7.56 \%)$ recorded. The distribution, box plot and the fitted normal distribution for each input variable are shown in figure 2 .
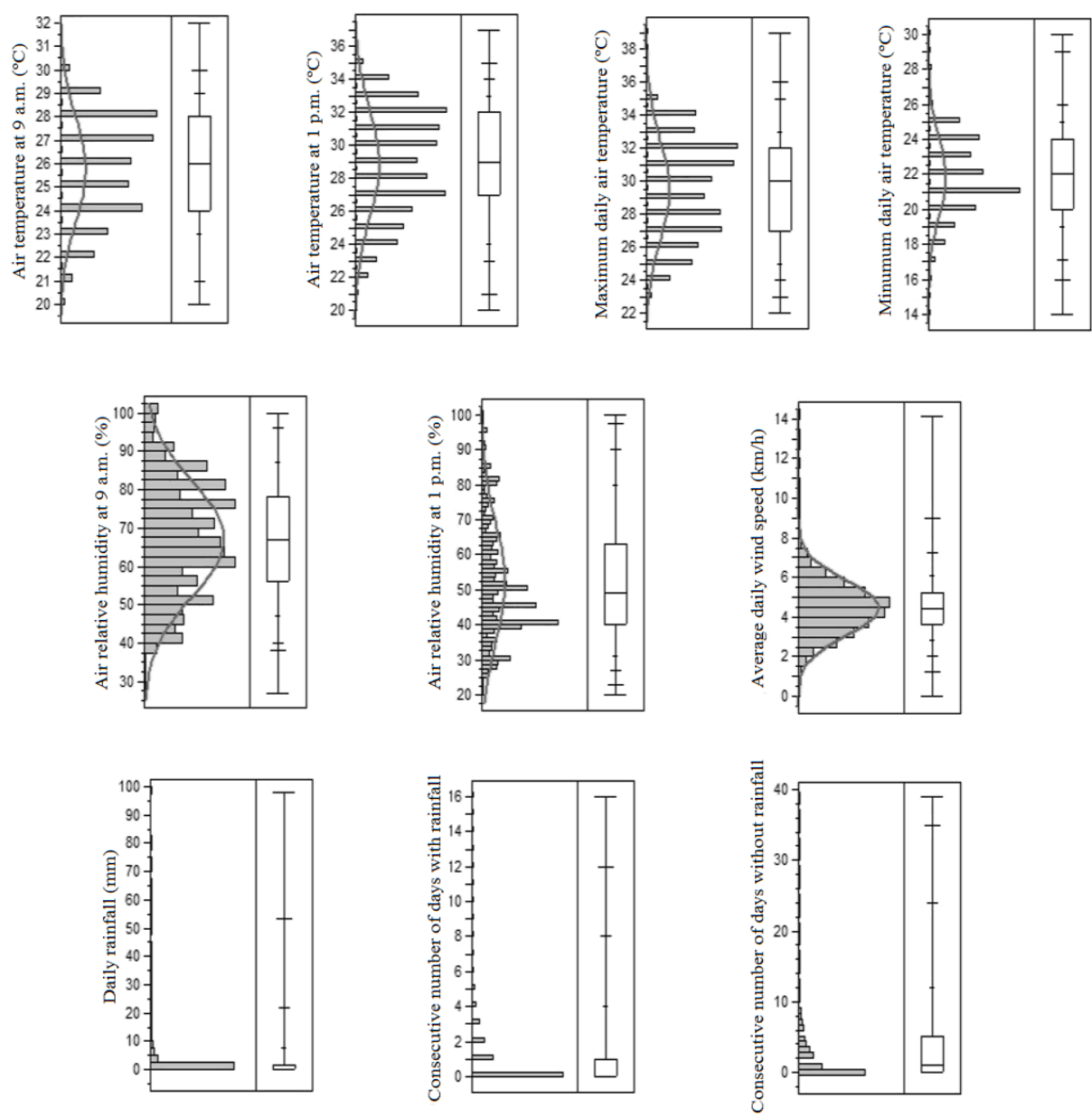

Figure 2. Distribution, normal line and box plot of the 10 inputs variables used to model the fire occurrence in eucalyptus plantations of the north coast of Bahia.

Figura 2. Distribuição, normal e box plot das 10 variáveis utilizadas para modelar a ocorrência de fogo em plantações de eucalipto no litoral norte da Bahia. 
Table 1 shows the meteorological parameters that revealed capacity to estimate the probability of fire occurrence $(\mathrm{p}<0.05)$, selected by stepwise logistic regression.

Table 1. Independent variables influent on the likelihood of fire occurrence $(\mathrm{p}<0.05)$ as selected by stepwise logistic regression.

Tabela 1. Influência das variáveis independentes selecionadas pela regressão logística stepwise ( $\mathrm{p}<0,05)$, na probabilidade de ocorrência de fogo.

\begin{tabular}{lccc}
\hline Variable & $\chi^{2}$ & $\mathbf{p}$ & Cumulative R $^{2}$ \\
\hline Maximum air temperature & 238.0 & 0.000 & 0.152 \\
Air relative humidity at 9 a.m. & 10.7 & 0.001 & 0.159 \\
Consecutive number of days with rainfall & 8.1 & 0.004 & 0.164 \\
Minimum air temperature & 7.6 & 0.006 & 0.169 \\
Wind speed & 5.1 & 0.024 & 0.172 \\
\hline
\end{tabular}

However, for the sake of parsimony and to facilitate the index calculation procedure, only the variables maximum air temperature, air relative humidity at 9 a.m. and consecutive number of days with rainfall greater or equal than $2 \mathrm{~mm}$ were selected for the model. The $\mathrm{R}^{2}$ increase corresponding to the remaining variables did not justify their inclusion in the model. The resulting logistic regression model was highly significant $\left(\chi^{2}=256.8 ; \mathrm{p}<0.0001\right)$, with $\mathrm{AUC}=0.806$, which indicates good discrimination:

$$
P f=\frac{1}{1+e^{\left[12.22+\left(-0.35 * T_{\max }\right)+\left(0.02 * H_{9 h}\right)+\left(0.31^{*} D_{w r}\right)\right]}}
$$

Where: $P f=$ daily probability of fire occurrence;

$e=$ base of the natural logarithms;

$T_{\max }=$ maximum daily air temperature $\left({ }^{\circ} \mathrm{C}\right)$;

$H_{9 h}=$ air relative humidity at 9 a.m. (\%);

$D_{w r}=$ consecutive number of days with rainfall greater or equal than $2 \mathrm{~mm}$ (if in the last $24 \mathrm{~h}$ there was no rain, $D_{w r}$ must be equal to zero).

\section{Defining the fire danger classes}

The values of $P f$ were classified into four distinct fire danger classes (Table 2). These fire danger classes were the best, based on the assumptions of Nunes et al. (2007) and Nunes et al. (2010), of several other classes with distinct limits tested.

Table 2. Forest fire danger classes according to the $P f$ value, and the daily fire occurrence probability based on the total number of days divided by the number of days with fire occurrence for each class.

Tabela 2. Classes de perigo de ocorrência de incêndio florestal de acordo com o valor de $P f$, e a probabilidade diária de ocorrência de fogo baseada no número total de dias dividido pelo número de dias com ocorrência de fogo para cada classe.

\begin{tabular}{lcc}
\hline Fire danger classes & $\boldsymbol{P f}$ & Observed fire occurrence probability (\%) \\
\hline High & $P f \geq 0.155$ & 22 \\
Average & $0.155>P f \geq 0.073$ & 13 \\
Low & $0.073>P f \geq 0.019$ & 3 \\
Very Low & $P f<0.019$ & 1 \\
\hline
\end{tabular}

Such classes indicate good performance since both assumptions of Nunes et al. (2007) and Nunes et al. (2010) are met. The class "very low" corresponds to 33\% of the days analyzed and accounted for only $2.7 \%$ of the days when fires occurred; $28 \%$ of the days were included in class "low" that represents $10.9 \%$ of the days with fire occurrences; class "average" $22.5 \%$ and $38.4 \%$, respectively; and the class "high" 16.5\% and 48\%, respectively (Figure 3). Nunes et al. (2007), using the Modified Monte 
Alegre Formula $\left(\mathrm{FMA}^{+}\right)$in several cities in the Brazilian state of Paraná, describes that good results for the $\mathrm{FMA}^{+}$were obtained when $27 \%$ or more of the days were classified in the danger class "null" and $23 \%$ or more of the days in danger class "low", and these classes responded, respectively, for values lower than $8.1 \%$ and lower than $12.5 \%$ of the total number of fire occurrences. Sturm et al. (2012), using the Canadian Fire Weather Index in Slovenia, reported that the class "very low" accounted for 3.7\% of the fires, while the class "low" accounted for $13.5 \%$. According to the authors, the index was found to be useful for practical applications such as the definition of fire danger classes consistent with fire activity.

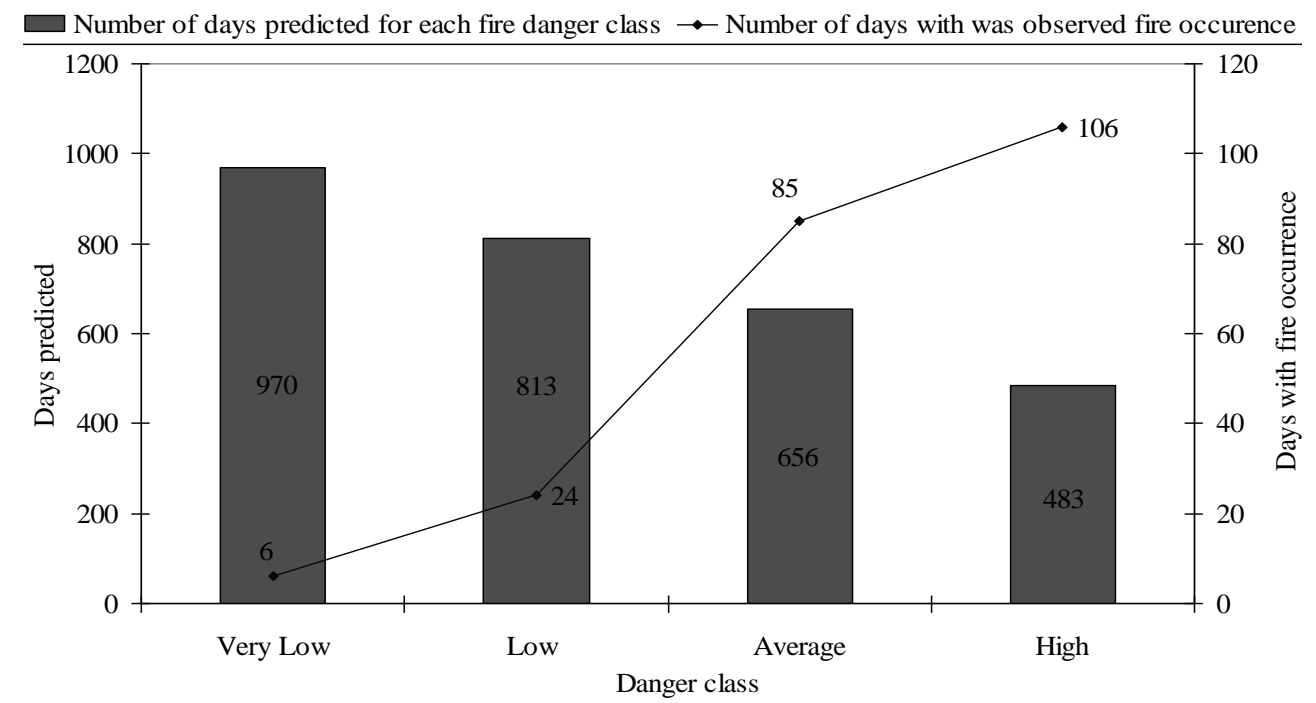

Figure 3. Total number of days (with or without fire occurrence) predicted for each Danger class (bars) and number of days with fire occurrence (line), between 2002 - 2010, for Copener Florestal Ltda. Eucalyptus plantations.

Figura 3. Número total de dias (com fogo e sem fogo) previstos para cada classe de perigo (colunas) e o número de dias com ocorrência de fogo (linha), entre 2002 e 2010, para as plantações de eucalipto da empresa Copener Florestal Ltda.

\section{Comparison with other models}

In order to apply the Skill Score procedure, the indexes had to be classified into only two classes: with or without fire occurrence probability (Table 3 ).

Table 3. Forest fire danger index thresholds.

Tabela 3. Valor limite dos índices de perigo de ocorrência de incêndios florestais.

\begin{tabular}{lc}
\hline Index & Threshold value for days without fire occurrence probability \\
\hline Proposed Index (White Model) & $<0.073$ \\
Angstrom Index & $\geq 2.5$ \\
Telicyn Logarithmic Index & $<3.6$ \\
Rodríguez and Moretti Index & $<25$ \\
Monte Alegre Formula & $<3.1$ \\
Modified Monte Alegre & $<8.1$ \\
Nesterov Index & $<301$ \\
Canadian Fire Weather Index & $<8.5$ \\
\hline
\end{tabular}

Although all models tested were highly significant in all statistical analyzes performed, the White Model herein showed higher efficiency over all others indexes tested (Table 4). In the logistic regression analysis, the Angstrom Index had the second highest $\mathrm{R}^{2}$, followed by the Canadian Fire Weather Index, while Nesterov had the worst result. In the Skill Score analysis, Telicyn Logarithmic 
Index had the second best result, followed by the Angstrom Index. The Rodríguez and Moretti index had the worst performance for this test, followed by the Nesterov Index.

White (2010), comparing the efficiency of several fire danger indexes in the Serra de Itabaiana National Park, Sergipe, Brazil found that the Angstrom Index presented the best statistical results, while the Telicyn Logarithmic Index and the Rodriguez and Moretti index showed the worst results. These results described by White (2010) were similar to the results found in this study that classify the Angstrom Index as having the best coefficient of determination $\left(\mathrm{R}^{2}\right)$, and the Telicyn and Nesterov Indexes having the worst results, respectively. Perhaps this similarity is due to the common weather patterns present in both study areas.

Table 4. Statistical performance analysis of the models used to predict the fire occurrence in eucalyptus plantations of the Copener Florestal Ltda. Company.

Tabela 4. Análise estatística do desempenho dos modelos testados para prever a probabilidade de ocorrência de fogo em plantações de eucalipto da empresa Copener Florestal Ltda.

\begin{tabular}{lccccc}
\hline Index & $\mathbf{R}^{\mathbf{2}}$ & $\mathbf{P}$ & AUC & Skill Score & $\begin{array}{c}\text { Percentage Success } \\
\text { Rate - (Accuracy) }\end{array}$ \\
\hline White Model & 0.164 & $<0.0001$ & 0.806 & 0.376 & 66.53 \\
Angstrom Index & 0.125 & $<0.0001$ & 0.778 & 0.093 & 47.60 \\
Canadian FWI Index & 0.102 & $<0.0001$ & 0.761 & 0.053 & 52.81 \\
Rodríguez and Moretti Index & 0.061 & $<0.0001$ & 0.718 & 0.017 & 17.28 \\
Monte Alegre Formula & 0.049 & $<0.0001$ & 0.756 & 0.062 & 40.08 \\
Monte Alegre Modified Formula & 0.049 & $<0.0001$ & 0.757 & 0.059 & 38.64 \\
Telicyn Logarithmic Index & 0.039 & $<0.0001$ & 0.726 & 0.118 & 62.11 \\
Nesterov Index & 0.037 & $<0.0001$ & 0.774 & 0.020 & 19.47 \\
\hline
\end{tabular}

The results obtained in this study corroborate the assumptions regarding the need to create specific and more efficient models to predict fire occurrence. In the coming years monitoring tests will be conducted with up to date data to validate the superiority of the White Model. Studies in other states in the Brazilian northeast are also suggested, using the model from this work to test its results in comparison to other indexes.

\section{CONCLUSIONS}

- The meteorological variables maximum daily air temperature, relative humidity at 9 a.m. and sequential number of days with rainfall greater than $2 \mathrm{~mm}$ were the main factors affecting fire occurrence in the study area.

- The model created (White Model) improved the ability to predict fire days over existent models, as shown by several statistics ( $\mathrm{R}^{2}$, AUC, Skill Score and Percentage Success Rates). Therefore, the use of this logistic model is recommended for the study area.

- Further analyzes should be performed to verify the applicability of this index in regions of similar climate.

\section{REFERENCES}

AGRESTI, A. An introduction to categorical data analysis. John Wiley and Sons, Inc, 1996, 400 p.

ANDREWS, P. L.; LOFTSGAARDEN, D. O.; BRADSHAW, L. S. Evaluation of fire danger rating indexes using logistic regression and percentile analysis. International Journal of Wildland Fire, v. 12, n. 2, p. 213 - 226, 2003.

CASTRO, F. X.; TUDELA, A.; SEBASTIÀ, M. T. Modeling moisture content in shrubs to predict firerisk in Catalonia (Spain). Agricultural and Forest Meteorology, v. 116, n. 1 - 2, p. 49 - 59, 2003.

COPENER Florestal Ltda. Histórico, geologia e solos. Relatório técnico, 2010. 12 p. 
FERNANDES, P. M. Estudo de adaptação para Portugal do Sistema Canadiano de Indexação do Perigo de Incêndio. Relatório para a Agência para a Prevenção de Incêndios, Universidade de Trás-osMontes e Alto Douro, 2005. 29 p.

FOGARTY, L. G.; PEARCE, H. G.; CATCHPOLE, W. R.; ALEXANDER, M. E. Adoption vs. adaptation: lessons from applying the Canadian Forest Fire Danger Rating System in New Zealand. In: 3RD INTERNATIONAL CONF. ON FOREST FIRE RESEARCH / 14TH FIRE AND FOREST METEOROLOGY CONF, 1998, Coimbra. Proceedings... Coimbra: ADAI, University of Coimbra, p. 1011 - 1028, 1998.

GOULD, J. S.; MCCAW, W. L.; CHENEY, N. P.; ELLIS, P. F.; KNIGHT, I. K.; SULLIVAN, A. L. Project Vesta - Fire in dry eucalypt forest: fuel structure, fuel dynamics and fire behaviour. EnsisCSIRO, Canberra ACT, and Department of Environment and Conservation, Perth, WA, 2007. 218 p.

INSTITUTO BRASILEIRO DE GEOGRAFIA E ESTATÍSTICA (IBGE). IBGE Cidades: Inhambupe. Disponível em: <http://www.ibge.gov.br/cidadesat/painel/painel.php?codmun=291370>. Acesso em: $15 / 08 / 2010$.

MAFALDA, V. G.; TORRES F. T. P.; RIBEIRO, G. A. Eficiência de índices de perigo de incêndios baseados em elementos climáticos no município de Juiz de Fora, MG. In: SIMPÓSIO BRASILEIRO DE GEOGRAFIA FÍSICA APLICADA, 13., 2009, Viçosa. Anais... Viçosa, 2009.

MELO, A. S.; JUSTINO, F.; LEMOS, C. F.; SEDIYAMA, G.; RIBEIRO, G. Suscetibilidade do ambiente a ocorrências de queimadas sob condições climáticas atuais e de futuro aquecimento global. Revista Brasileira de Meteorologia, v. 26, n. 3, p. 401 - 418, 2011.

NARCISO, M. G.; SORIANO, B. M. A.; DANIEL, O.; MÁXIMO, F. A. Proposta de método para seleção de indicador de risco de incêndio por região. Embrapa Pantanal, Corumbá, 2011. 13 p.

NIAZI, M. A.; SIDDIQUE, Q.; HUSSAI, A.; KOLBERG, M. Verification \& validation of an agent-based forest fire simulation model. In: 2010 SPRING SIMULATION MULTICONFERENCE, 10., 2010, San Diego. Proceedings... San Diego, CA, USA: Society for Computer Simulation International, 2010.

NUNES, J. R. S.; SOARES, R. V.; BATISTA, A. C. Ajuste da Fórmula de Monte Alegre Alterada $\left(\mathrm{FMA}^{+}\right)$pra o estado do Paraná. Revista Floresta, Curitiba, PR, v. 37, n. 1, p. 1 - 14, 2007.

NUNES, J. R. S.; FIER, I. S. N.; SOARES, R. V.; BATISTA, A. C. Desempenho da Fórmula de Monte Alegre (FMA) e da Fórmula de Monte Alegre Alterada (FMA+) no distrito florestal de Monte Alegre. Revista Floresta, v. 40, n. 2, p. 319 - 326, 2010.

PALHEIRO, P. M.; FERNANDES, P. M.; CRUZ, M. G. A fire behaviour-based fire danger classification for maritime pine stands: comparison of two approaches. Forest Ecology and Management, v. 234, p. 1 - 12, 2006.

POLLACK, H. N. Uncertain science ... uncertain world. Cambridge University Press, 2003, 256 p.

SAMPAIO, O. B. Análise da eficiência de quatro índices na previsão de incêndios florestais para a região de Agudos, SP. 157 f. Tese (Doutorado em Engenharia Florestal) - Setor de Ciências Agrárias, Universidade Federal do Paraná, Curitiba, 1999.

SANTOS, J. F.; SOARES, R. V.; BATISTA, A. C. Perfil dos incêndios florestais no Brasil em áreas protegidas no período de 1998 a 2002. Revista Floresta, Curitiba, v. 36, n. 1, p. 93 - 100, 2006.

SILVA, I. D. B.; PONTES JR., C. F. Elaboração de um fator de risco de incêndios florestais utilizando Lógica Fuzzy. Biomatemática, v. 21, p. 113 - 128, 2011.

SOARES, R. V. Determinação de um índice de perigo de incêndio para a região centro-paranaense, Brasil. 72 f. Dissertação (Mestrado em Engenharia Florestal) - Centro Agronômico Tropical de Enseñanza e Investigacion, Turrialba, Costa Rica, CATIE/IICA, 1972. 
SOARES, R. V.; BATISTA, A. C. Incêndios florestais: controle, efeitos e uso do fogo. Curitiba, 2007. $264 \mathrm{p}$.

STURM, T.; FERNANDES, P. M.; SUMRADA, R. The Canadian fire weather index system and wildfire activity in the Karst forest management area, Slovenia. European Journal of Forest Research, v. 131, p. $829-834,2012$.

VIEIRA, A. T.; MELO, F.; LOPES, H. B. V; CAMPOS, J. C. V.; BOMFIM, L. F. C.; COUTO, P. A. A.; BEVENUTI, S. M. P. Projeto cadastro de fontes de abastecimento por água subterrânea: diagnóstico do município de Inhambupe. Ministério de Minas e Energia, Salvador, 2005. 26 p.

WHITE, B. L. A. Incêndios florestais no Parque Nacional Serra de Itabaiana, Sergipe. 142 f. Dissertação (Mestrado em Desenvolvimento e Meio Ambiente) - Universidade Federal de Sergipe. São Cristóvão, 2010.

WHITE, B. L. A.; WHITE, L. A. S.; RIBEIRO, G. T.; MELO e SOUZA, R.; ALVES, J. M.; MOURA, F. R. Análise da eficiência dos principais índices de perigo de ocorrência de incêndios florestais em povoamentos de eucalipto na região do litoral norte da Bahia, Brasil. In: CONGRESSO DE ECOLOGIA DO BRASIL, 10., 2011, São Lourenço. Anais... São Lourenço, MG: Sociedade de Ecologia do Brasil, 2011.

WHITE, L. A. S. Análise espacial e temporal de incêndios florestais para o município de Inhambupe, litoral norte da Bahia. 98 f. Dissertação (Mestrado em Agroecossistemas) - Universidade Federal de Sergipe. São Cristóvão, 2013. 
